\title{
The Role, Status, and Working Conditions of Paraprofessionals: A National Survey of Academic Libraries
}

\section{Larry R. Oberg, Mark E. Mentges, P. N. McDermott, and Vitoon Harusadangkul}

\begin{abstract}
The emergence of paraprofessionals as a growing force in academic libraries is a much discussed but little investigated phenomenon. The rapid change that characterizes academic libraries today has affected profoundly staff deployment and workplace task assignment. The profession's response to these new conditions, however, has been weak, and librarians have not exercised leadership. Librarians speculate, but do not know with certainty, the education, skills, and other competencies required of paraprofessionals, the tasks and levels of authority assigned them, the salaries and staff development incentives offered, or the potential of their contribution. The authors present the results of their 1990 national survey of the role, status, and working conditions of paraprofessionals in two populations, a census of the Association of Research Libraries, and a random sample of the Carnegie Classification libraries. They review the literature, analyze the data results, make recommendations for further research, and propose actions to be taken by the profession.
\end{abstract}

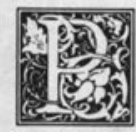

ersonnel utilization and role definition have been persistent problems within librarianship. The separation of workplace tasksintocategoriesunambiguously defined by their levels of complexity and consistently performed by staff with appropriate educational qualifications and training continues to elude the profession. A high degree of overlap has come to exist between the work performed by librarians and that performed by support staff, particularly paraprofessionals. ${ }^{1}$ Task overlap contributes to the role blurring that has plagued generations of library workers.
Role blurring confuses the library's clientele and contributes to the generalized impression that there is little difference between the work performed by librarians and that performed by support staff. Many librarians compound this problem, often to the point of professional embarrassment, by continuing to perform once innovative but now routine work that should be delegated to competent paraprofessionals. Unfortunately, librarianship does not possess a mechanism to censure or prevent this abuse.

Task overlap and role blurring degrade the quality of client-library contacts. In

Larry R. Oberg is Director of Libraries, Albion College, Albion, MI 49224; Mark E. Mentges is Head, Circulation Division, Education-Psychology Library, University of California, Berkeley, CA 94720; P. N. McDermott may be contacted at 199 River Oaks Drive, Plymouth, MI 48170; Vitoon Harusadangkul is a mathematics and physics double major at Albion College. The authors thank the Association of College and Research Libraries for financial and technical assistance on this project. 
academic libraries, these factors hinder the acceptance of librarians as colleagues of the teaching faculty and as experts by their clients generally. Task overlap also creates resentment among support staff, who see themselves performing the same duties librarians perform, only for less money and less prestige.

The rapid change that characterizes today's library workplace contributes to the problems of personnel deployment and use, task overlap, and role blurring. ${ }^{2}$ Some of the forces that account for this accelerated rate of change include:

- the automation of library processes and the growth of networking;

- the creation of new tasks and shifts within the status hierarchy of many old ones;

- static or declining budgets;

- the research, teaching, and governance demands that faculty status has required of librarians,

- the move away from administrative models based on authority toward those based on consensus and participation;

- the emergence of a true paraprofessional level of employment, and;

- a new generation of committed, increasingly vocal paraprofessionals.

Although automation and other change agents contribute to role blurring, they also create exciting new opportunities for librarians as well as support staff. It is particularly vexing, therefore, to find professionals who persist in defining their positions by other than their highest-level responsibilities.

The response of the profession to the problems of staff utilization and role definition has been weak. Librarians have shown little inclination to exercise leadership in these areas. The Library Education and Personnel Utilization (LEPU) document dates from 1970 and remains the profession's only national policy statement. ${ }^{3}$ LEPU proposes two professional and three support staff grades, thereby implicitly acknowledging and codifying a paraprofessional class of employment. Although it has been widely ignored at the grass roots level, the LEPU document is nonetheless a milestone in the evolution of staff differentiation. It does not, however, serve the profession well as a guide to the division of tasks and responsibilities between the various support staff levels it proposes or, for that matter, between paraprofessionals and librarians. Currently under review, the revised LEPU document may define less ambiguously the roles of both groups, although a full resolution of the problem may require nothing less than a redefinition of librarianship. ${ }^{4}$

The response of the profession to the problems of staff utilization and role definition has been weak.

Finding a solution to these problems is hampered by a lack of concrete data on the role, status, and working conditions of paraprofessionals and other library support staff. Speculation is based largely upon anecdotal evidence, and librarians do not know with certainty what competencies are required of paraprofessionals, what they are assigned to do, how well or poorly they are treated, how involved they are in library processes, and the extent of their potential contribution. This broad descriptive survey was designed to elicit preliminary data that may shed light upon some of these questions. ${ }^{5}$

The authors chose to survey paraprofessionals rather than all support staff because the emergence of paraprofessionalism within American libraries is a comparatively recent phenomenon, the work assigned to paraprofessionals is of a high order and specific to libraries, and the broadest band of task overlap within the library workplace most likely exists between librarians and paraprofessionals. Conclusions are drawn from the data, and areas for further research and recommendations to the profession are proposed.

\section{THE LITERATURE}

A limited but growing North American literature describes the role, status, and working conditions of paraprofessionals in academic libraries. Until recently, much of it has addressed their 
use and effectiveness at the reference desk and their ability to perform high level technical services duties not previously assigned them. Because of a new wave of interest, this literature shows signs of expanding and diversifying. J. Keith Ostertag's "Annotated Bibliography: Library Paraprofessionals, 19651991" is the best currently available guide to the general literature on the topic. 6

\section{Historical Literature}

The emergence of paraprofessionals as a class has been traced by Charlotte Mugnier in her brief 1980 monograph entitled The Paraprofessional and the Professional Job Structure. ${ }^{7}$ Charles W. Evans reviews the development of support staff since the late 1800 s in a paper entitled "The Evolution of Paraprofessional Library Employees." ${ }^{8}$ The historical context that shaped the changes in the professional status of librarians in both the United States and Canada is discussed by Olga B. Bishop in The Use of Professional Staff in Libraries: A Review 1923-1971.9

The first wave of widespread interest in support staff issues and emergent library paraprofessionalism occurred in the late 1960 s and early 1970 s. Debates within the profession raged around the issues of support staff classification and use. A number of papers from that period documented and, indeed, influenced the development of paraprofessionalism in North American libraries. Many remain of immediate or historical interest. Lester Asheim made several important contributions to this debate, including "Education and Manpower for Librarianship: A Position Paper Suggesting First Steps Toward a Statement of Policy." Asheim's work was instrumental in the formulation and adoption of the LEPU policy statement. ${ }^{10}$

In his 1967 dissertation research project, Charles A. Bunge gathered data on the relationship between formal library education and reference efficiency. Bunge reported the trained participants to be significantly more efficient than the untrained, although he found little difference between the two groups in the ratio of questions answered correctly. Bunge's study triggered a debate that continues today on the advisability of using paraprofessionals at the reference desk." Louis Shores' 1968 paper entitled "Library Technician: A Professional Opportunity" advocates educational standards for this "middle group," whose intensified utilization, he suggests, offers librarians the opportunity to assume "the high role in our society for which we are destined." ${ }^{12}$ Leo Nelson Flanagan's 1974 article entitled "A Sleeping Giant Awakens: The Unionization of Library Support Staffs" captures the militant spirit of a period of intense organizing on many of the nation's campuses. ${ }^{13}$

In an important essay, "The Management of Libraries and the Professional Functions of Librarians," Ralph M. Edwards describes the tension and confusion that exist between the professional duties of librarians and library management tasks. ${ }^{14}$ Only when librarians are freed from mundane tasks, Edwards contends, will the profession flourish. Ostertag suggests that Edwards' article "lays the foundation for later discussions concerning task shifting from professionals to paraprofessionals."

\section{Contemporary Literature}

Of the articles that provide a context for the study of library paraprofessionalism today, perhaps the most useful is Margaret Myers' "Staffing Patterns," an authoritative overview of changes in library staff deployment and utilization. ${ }^{15}$ Myers discusses duties, organizational structures, standards, policies, regulations, and external and internal forces that affect all library staff, including paraprofessionals. In a 1981 article entitled "Improving the Effectiveness of Libraries through Improvements in the Quality of Working Life," Charles Martell proposes a redesigned library work environment that he suggests will improve the services libraries offer and the ability of library staff to cope with rapid change and enhance the quality of library work life. ${ }^{16}$ Robert E. Molyneux's "Staff Patterns and Library Growth at ARL Libraries, 1962/63 to 1983/84," re- 
views expenditures for personnel and reports an increase in the ratio of support staff to librarians. ${ }^{17}$

In a seminal 1982 article entitled "Continuity or Discontinuity-A Persistent Personnel Issue in Academic Librarianship," Allen B. Veaner challenges the profession to come to grips with its longstanding problems of personnel utilization. ${ }^{18}$ His later two-part paper, "1985 to 1995: The Next Decade in Academic Librarianship," anticipates change and assesses its implications for the status, welfare, and contribution of library personnel and the profession generally. ${ }^{19}$

The forces that are changing the role and status of both professionals and paraprofessionals were discussed in 1986 by Joanne R. Euster in her brief but still useful "Changing Staffing Patterns in Academic Libraries." ${ }^{20}$ Kathleen M. Heim and Debbie Wolcott review problems of support staff nomenclature and definition, the development of ALA policy on staff deployment, and compare library paraprofessionals with their counterparts in law and medicine in their article entitled "Staff Utilization in Libraries." ${ }^{21}$ In a 1992 essay entitled "The Emergence of the Paraprofessional in Academic Libraries: Perceptions and Realities," Larry R. Oberg assesses the impact of this phenomenon upon the library workplace and analyzes the problems it poses for the profession. ${ }^{22}$

\section{Non-U.S. Literature}

Numerous essays on library support staff have been published outside the United States. These studies are often more objective and less exhortative than those published here, but they have not been cited extensively. They add perspective and deserve closer attention. In 1981, John Levett compared library paraprofessionals with their counterparts in social work and medicine in "Paraprofessional Workers in Four Fields: A Comparative Study." ${ }^{23}$ Ian M. Johnson reviews the development of library technicians in the United States, Czechoslovakia, Hungary, and Australia in "The Development of Library Technicians: A Review of Experience in Selected Countries." 24
The pressures that lead to the emergence of paraprofessionalism are analyzed in Brian A. Nettlefold's study entitled "Paraprofessionalism in Librarianship." 25 The division between professional and support staff within information science and librarianship is treated by Karen Beales in a 1989 study entitled "Non-professional Information and Training." 26

The political and historical contexts that have shaped the changes in the education and deployment of library support staff in England are discussed by Donald E. Davinson in his "Non-professional Library Staff Education: A State of the Art Report and Proposals for the Future."27 Education for support staff within the English context is discussed by Josephine Webb in "The Non-professional in the Academic Library: Education for Paraprofessionalism."28 Finally, Helen Smeaton describes the role and history of library technicians in the Australian work force in "Library Technicians in Australia: Past, Present and Future."29

\section{STUDY DESIGN}

The basic objectives of this study are to determine the competencies required of paraprofessionals, how they are treated, and what they are assigned to do in the academic library workplace. The authors also wished to ascertain any discernible patterns in the role, status, and working conditions of paraprofessionals that are attributable to the size of the library, the type of institutional control exercised (public or private), or the gender composition of the staff. These topics are much discussed, but little investigated.

Because this is a broad descriptive survey, formal hypotheses were not elaborated. Nonetheless, a number of questions guided the research:

- What is the ratio of paraprofessionals to librarians and has that ratio changed over time?

- What entry-level educational degrees are required of paraprofessionals and what degree levels have been attained by incumbents? 
- To what extent are certain skills and competencies required of paraprofessionals?

- To what extent are paraprofessionals assigned work traditionally performed by librarians?

- What level of administrative authority is assigned to paraprofessionals?

- To what extent are paraprofessionals involved in the governance of academic libraries?

- To what extent does salary overlap occur between librarians and paraprofessionals?

- To what control groups are paraprofessionals compared when salaries are reviewed?

- To what extent are certain staff development incentives made available to paraprofessionals? And,

- What is the average length of employment of paraprofessionals in academic libraries?

Responses to all of these questions, in the form of data or comment, are included in the tables and the Survey Results and the Discussion sections of this report.

\section{SURVEY METHODOLOGY}

With financial and technical support for the project provided by the Association of College and Research Libraries (ACRL), the authors developed an original 21-question survey instrument. This questionnaire was designed to elicit information on the discernible differences in the role, status, and working conditions of paraprofessionals and librarians. It includes a 150-word definition of the term paraprofessional and a 50-word definition of librarian. ${ }^{30} \mathrm{~A}$ copy of the survey instrument is available from the authors. After review by numerous librarians and other academics, the questionnaire was pretested in approximately 40 academic libraries.

\section{Sample Characteristics}

In January 1990, the questionnaire and a cover note printed on ACRL stationery were sent to two distinct populations. ${ }^{31}$ The first and larger of the two is composed of a random sample of 488 librar- ies drawn from the 2,747 institutions listed in the 1987 edition of the Carnegie Foundation's A Classification of Institutions of Higher Education. This sample includes $17 \%$ of all public and $11 \%$ of all private institutions in the Carnegie Classification categories chosen for the survey. ${ }^{32}$

Three hundred and ninety usable responses were received from this population, yielding a return rate of $80 \%$. Thirty-four questionnaires-mainly, but not exclusively, from small two-year institutions-were returned partially completed because these libraries reported that they employed no paraprofessionals as they were defined in the survey.

\section{The basic objectives of this study are to determine the competencies required of paraprofessionals, how they are treated, and what they are assigned to do in the workplace.}

The second population is composed of 108 members of the Association of Research Libraries (ARL) in the United States and Canada. Seventy-seven usable responses were received for a return rate of $71 \%$ (see table 1 ). This second population was chosen because it constitutes a well-defined group of libraries that represents, however imperfectly, the elite of the North American research library world. The ARL libraries also employ a disproportionately high percentage of all academic library employees. Finally, because the ARL membership is chosen frequently as the subject of research, the authors wished to add to the existing body of data and help flesh out the profile of this important group.

The data from both the Carnegie Classification and the ARL samples were sorted by institution, type of institutional control (public or private), and by the number and the gender of the paraprofessional subjects. The Carnegie sample data were sorted by five Carnegie Classification institutional categories as well as globally. ${ }^{33}$ Although the $A R L$ institutions are included in the Car- 
TABLE 1

INSTITUTIONAL CHARACTERISTICS

\begin{tabular}{|c|c|c|c|c|}
\hline Characteristic & $\begin{array}{c}\text { Total } \\
\text { Population }\end{array}$ & $\begin{array}{c}\text { Sample } \\
\text { Population }\end{array}$ & $\begin{array}{c}\% \\
\text { Total } \\
\end{array}$ & $\begin{array}{c}\% \\
\text { Sample }\end{array}$ \\
\hline \multicolumn{5}{|l|}{ Type of Control } \\
\hline \multicolumn{5}{|l|}{ Carnegie Classification } \\
\hline Public & 1,482 & 246 & 16.6 & 63.1 \\
\hline Private & 1,265 & 144 & 11.4 & 36.9 \\
\hline \multicolumn{5}{|l|}{ ARL sample } \\
\hline Public & 70 & 55 & 64.9 & 71.4 \\
\hline Private & 38 & 22 & 57.9 & 28.6 \\
\hline \multicolumn{5}{|l|}{ Carnegie Classification } \\
\hline Research university I, research university II & 104 & 15 & 14.4 & 3.8 \\
\hline Doctorate-granting I, doctorate-granting II & 109 & 12 & 11.0 & 3.1 \\
\hline Comprehensive I, comprehensive II & 595 & 90 & 15.1 & 23.1 \\
\hline Liberal arts I, liberal arts II & 572 & 89 & 15.6 & 22.8 \\
\hline Two-year institutions & 1,367 & 184 & 13.5 & 47.2 \\
\hline$A R L$ & 108 & 77 & 71.3 & 100.0 \\
\hline \multicolumn{5}{|l|}{ Volumes in library } \\
\hline \multicolumn{5}{|l|}{ Carnegie Classification } \\
\hline 0 to 24,999 & & 52 & & 13.4 \\
\hline 25,000 to 49,999 & & 87 & & 22.3 \\
\hline 50,000 to 99,999 & & 79 & & 20.3 \\
\hline 100,000 to 249,999 & & 96 & & 24.6 \\
\hline 250,000 to 499,999 & & 39 & & 10.0 \\
\hline 500,000 to 749,999 & & 13 & & 3.3 \\
\hline 750,000 to $1,000,000$ & & 4 & & 1.0 \\
\hline More than $1,000,000$ & & 20 & & 5.1 \\
\hline
\end{tabular}

*-For the ARL sample, 76 of the 77 reporting institutions hold more than 1 million volumes.

negie Classification, no overlap exists between the two samples. In the tables that accompany this report, the data generated by the Carnegie Classification categories of research universities and doctorategranting colleges and universities have been collapsed into a single category. ${ }^{34}$

The smallest library in the survey reports holdings of 2,000 volumes; the largest seven million. Within the ARL sample, 76 of the 77 responding libraries report holdings of more than one million volumes. There is a total of 3,235 paraprofessional jobs in the Carnegie and 6,231 in the ARL sample libraries; the total number of librarian positions in the
Carnegie sample is 2,940 and the total number in the ARL sample is 4,704 . Within the Carnegie sample, there is a ratio of 1.10 paraprofessional to 1 librarian and a ratio of 4.40 female to 1 male paraprofessional. Within the ARL sample, the corresponding figures are 1.32:1 and 3.07:1 (see table 2).

\section{SURVEY RESULTS}

The survey data indicate that important changes have occurred in the ratio of librarians to paraprofessionals over the past twenty years. One-fourth of all respondents $-24 \%$ of the Carnegie sample and $27 \%$ of the ARL sample-re- 
TABLE 2

POPULATION CHARACTERISTICS

\begin{tabular}{llll}
\hline & & \multicolumn{2}{c}{ Ratio of } \\
\cline { 3 - 4 } Population Sample & $\begin{array}{c}\text { No. of } \\
\text { Paraprofessionals }\end{array}$ & $\begin{array}{c}\text { Paraprofessionals to } \\
\text { Librarians }\end{array}$ & $\begin{array}{c}\text { Female-to-Male } \\
\text { Paraprofessionals }\end{array}$ \\
\hline $\begin{array}{c}\text { Carnegie Classification } \\
\text { Research university I, research } \\
\text { university II }\end{array}$ & $1,066.5$ & & \\
$\begin{array}{l}\text { Doctorate-granting I, doctorate- } \\
\text { granting II }\end{array}$ & 378.0 & 1.15 & 2.68 \\
$\begin{array}{l}\text { Comprehensive I, comprehensive II } \\
\text { Liberal arts I, liberal arts II }\end{array}$ & 792.0 & 1.44 & 5.18 \\
Two-year institutions & 446.0 & 0.98 & 6.12 \\
Total & 552.0 & 1.09 & 7.14 \\
ARL & $3,234.5$ & 1.10 & 5.19 \\
\hline
\end{tabular}

* This ratio was calculated by dividing the total number of paraprofessionals by the total number of librarians.

port more paraprofessionals and fewer librarians on their staffs today than in the past. Less than half- $44 \%$ of the Carnegie and $40 \%$ of the ARL sample respondents-report that the ratio has remained the same. Only $11 \%$ of the Carnegie and $8 \%$ of the ARL sample respondents report fewer paraprofessionals and more librarians than in the past. Another $8 \%$ of the Carnegie Classification and $14 \%$ of the ARL respondents suggest that something else has occurred, most often noting that the number of librarians has remained constant while the number of paraprofessionals has increased. Thirteen percent of the Carnegie and $10 \%$ of the ARL respondents report that they do not know if change has occurred in the composition of their staffs.

\section{Education}

Educational requirements for paraprofessionals vary widely by size and type of library. The educational levels attained by incumbents are often higher than what is required for their jobs. The data indicate that $93 \%$ of all responding ARL sample libraries require a high school degree of all or some of their paraprofessionals, $58 \%$ an associate degree, $76 \%$ a bachelor's degree, and $24 \%$ a graduate degree. The corresponding figures for the Carnegie sample libraries are $98 \%$, a high school degree; $62 \%$, an associate degree; $64 \%$, a bachelor's degree; and $9 \%$, a graduate degree (see table 3 ).

Ninety-seven percent of the ARL and $65 \%$ of the Carnegie sample libraries report that they employ at least some paraprofessionals who hold a degree higher than that required for the job (see table 4).

\section{Skills and Competencies}

A number of higher-level skills and competencies are required of paraprofessionals in a high percentage of the libraries surveyed. For example, computer skills are required of all or some paraprofessionals by $96 \%$ of the responding ARL and by $93 \%$ of the responding Carnegie sample libraries. Supervisory skills are required by $97 \%$ and administrative skills by $89 \%$ of the responding libraries within the ARL sample. The corresponding percentages for the Carnegie sample are 90 and 64 . The requirements for interpersonal, oral, and written communication skills are also high (see table 5).

Foreign language skills are required primarily by the large research libraries, a fact that no doubt reflects their more specialized collection needs. Eighty-one percent of the responding ARL sample libraries require foreign language skills of some or all of their paraprofessionals, 
TABLE 3

FORMAL EDUCATIONAL DEGREES REQUIRED OF PARAPROFESSIONALS

\begin{tabular}{|c|c|c|c|c|c|}
\hline \multirow[b]{2}{*}{ Population Sample } & \multicolumn{5}{|c|}{ Degree } \\
\hline & $\begin{array}{c}\text { High School } \\
(\%)\end{array}$ & $\begin{array}{c}\text { Associate } \\
(\%)\end{array}$ & $\begin{array}{c}\text { Bachelor's } \\
(\%)\end{array}$ & $\begin{array}{c}\text { Graduate } \\
(\%)\end{array}$ & $\begin{array}{c}\text { Other } \\
(\%)\end{array}$ \\
\hline Total Carnegie Classification & $(\mathrm{N}=348)$ & $(\mathrm{N}=211)$ & $(\mathrm{N}=237)$ & $(\mathrm{N}=140)$ & $(\mathrm{N}=79)$ \\
\hline \multicolumn{6}{|l|}{ Required of: } \\
\hline All & 91 & 26 & 23 & 0 & 20 \\
\hline Some & 7 & 36 & 41 & 9 & 5 \\
\hline None & 2 & 37 & 36 & 91 & 75 \\
\hline$A R L$ & $(\mathrm{~N}=73)$ & $(\mathrm{N}=54)$ & $(\mathrm{N}=71)$ & $(\mathrm{N}=55)$ & $(\mathrm{N}=21)$ \\
\hline \multicolumn{6}{|l|}{ Required of: } \\
\hline All & 79 & 4 & 13 & 0 & 24 \\
\hline Some & 14 & 54 & 63 & 24 & 14 \\
\hline None & 7 & 43 & 24 & 76 & 62 \\
\hline \multicolumn{6}{|l|}{ Gender } \\
\hline Female & $(\mathrm{N}=206)$ & $(\mathrm{N}=114)$ & $(\mathrm{N}=125)$ & $(\mathrm{N}=69)$ & $(\mathrm{N}=51)$ \\
\hline \multicolumn{6}{|l|}{ Required of: } \\
\hline All & 93 & 31 & 29 & 0 & 24 \\
\hline Some & 6 & 33 & 30 & 6 & 6 \\
\hline None & 1 & 36 & 42 & 94 & 71 \\
\hline Male & $(\mathrm{N}=75)$ & $(\mathrm{N}=47)$ & $(\mathrm{N}=59)$ & & $(\mathrm{N}=13)$ \\
\hline \multicolumn{6}{|l|}{ Required of: } \\
\hline All & 89 & 28 & 24 & 0 & 7 \\
\hline Some & 9 & 40 & 51 & 16 & 8 \\
\hline None & 1 & 32 & 25 & 84 & 85 \\
\hline
\end{tabular}

TABLE 4

LIBRARIES EMPLOYING PARAPROFESSIONALS WHO HOLD EDUCATIONAL DEGREES HIGHER THAN THOSE REQUIRED FOR THEIR POSITIONS

Response

Libraries That Employ:

Population Sample Some $(\%)$

None (\%)

Total Carnegie Classification $(N=351)$

$A R L(N=77)$

65 35

Gender

Female $(\mathrm{N}=210)$

55

Male $(\mathrm{N}=75)$

75

while these skills are required by only $3 \%$ of the two-year community, junior, and technical colleges and $18 \%$ of the liberal arts college libraries in the Carnegie sample.

\section{Tasks Assigned}

Eighty-eight percent of all responding ARL sample libraries regularly schedule paraprofessionals to work at their refer- 
TABLE 5

SKILLS AND OTHER COMPETENCIES REQUIRED OF PARAPROFESSIONALS

Skill

\begin{tabular}{|c|c|c|c|c|c|c|c|}
\hline \multirow[b]{2}{*}{$\begin{array}{l}\text { Population } \\
\text { Sample }\end{array}$} & \multicolumn{7}{|c|}{ Skill } \\
\hline & $\begin{array}{c}\text { Foreign } \\
\text { Language } \\
(\%)\end{array}$ & $\begin{array}{c}\text { Computer } \\
(\%)\end{array}$ & $\begin{array}{c}\text { Oral and } \\
\text { Written } \\
\text { Com- } \\
\text { munication } \\
(\%)\end{array}$ & $\begin{array}{c}\text { Supervisory } \\
(\%)\end{array}$ & $\begin{array}{c}\text { Adminis- } \\
\text { trative } \\
(\%)\end{array}$ & $\begin{array}{c}\text { Inter- } \\
\text { personal } \\
(\%)\end{array}$ & $\begin{array}{l}\text { Other } \\
(\%)\end{array}$ \\
\hline $\begin{array}{l}\text { Total Carnegie } \\
\text { Classification }\end{array}$ & $(\mathrm{N}=307)$ & $(\mathrm{N}=344)$ & $(\mathrm{N}=347)$ & $(\mathrm{N}=343)$ & $(\mathrm{N}=323)$ & $(\mathrm{N}=346)$ & $(\mathrm{N}=35)$ \\
\hline \multicolumn{8}{|l|}{ Required of: } \\
\hline All & 2 & 35 & 70 & 34 & 13 & 80 & 23 \\
\hline Some & 13 & 58 & 26 & 56 & 51 & 17 & 29 \\
\hline None & 85 & 7 & 4 & 10 & 36 & 3 & 49 \\
\hline$A R L$ & $(\mathrm{~N}=76)$ & $(\mathrm{N}=77)$ & $(\mathrm{N}=76)$ & $(\mathrm{N}=75)$ & $(\mathrm{N}=73)$ & $(\mathrm{N}=74)$ & $(\mathrm{N}=10)$ \\
\hline \multicolumn{8}{|l|}{ Required of: } \\
\hline All & 1 & 21 & 57 & 7 & 3 & 53 & 20 \\
\hline Some & 80 & 75 & 41 & 90 & 86 & 47 & 40 \\
\hline None & 18 & 4 & 3 & 3 & 11 & 0 & 40 \\
\hline
\end{tabular}

TABLE 6

LIBRARIES THAT REGULARLY SCHEDULE PARAPROFESSIONALS AT THE REFERENCE/INFORMATION DESK AND RESTRICTIONS IMPOSED

\begin{tabular}{|c|c|c|c|c|}
\hline \multirow[b]{2}{*}{ Population Sample } & \multicolumn{4}{|c|}{ Restriction Imposed } \\
\hline & $\begin{array}{c}\text { None } \\
(\%)\end{array}$ & $\begin{array}{l}\text { Librarian } \\
\text { Required as } \\
\text { Backup } \\
(\%)\end{array}$ & $\begin{array}{l}\text { Other } \\
(\%)\end{array}$ & $\begin{array}{l}\text { Not Permitted to } \\
\text { Work } \\
(\%)\end{array}$ \\
\hline \multicolumn{5}{|l|}{ Carnegie Classification } \\
\hline $\begin{array}{l}\text { Research/doctoral } \\
(\mathrm{N}=27)\end{array}$ & 63 & 15 & 0 & 22 \\
\hline $\begin{array}{l}\text { Comprehensive } \\
\text { university }(\mathrm{N}=85)\end{array}$ & 40 & 8 & 1 & 51 \\
\hline Liberal arts $(\mathrm{N}=86)$ & 57 & 9 & 6 & 28 \\
\hline Two-year (N=156) & 54 & 13 & 5 & 28 \\
\hline Total $(\mathrm{N}=354)$ & 52 & 11 & 3 & 33 \\
\hline$A R L(N=77)$ & 68 & 14 & 6 & 12 \\
\hline \multicolumn{5}{|l|}{ Gender } \\
\hline Female $(\mathrm{N}=210)$ & 49 & 11 & 5 & 35 \\
\hline Male $(\mathrm{N}=77)$ & 69 & 12 & 1 & 18 \\
\hline
\end{tabular}

ence or information desks. Twenty percent of these libraries impose restrictions upon their performance, typically requiring a librarian to be present as backup. Of the total Carnegie sample, $66 \%$ regularly schedule paraprofessionals at their reference or information desks. Fourteen per- cent of this group impose equivalent restrictions (see table 6). Size of library appears to be a factor, with large research libraries more likely than smaller ones to use paraprofessionals at these desks.

When the data from the Carnegie sample are sorted by number of para- 
TABLE 7

LIBRARIES THAT REGULARLY SCHEDULE PARAPROFESSIONALS TO PERFORM DIALOG, BRS, ORBIT, OR SIMILAR ONLINE DATABASE SEARCHES AND RESTRICTIONS IMPOSED

\begin{tabular}{|c|c|c|c|c|}
\hline \multirow[b]{2}{*}{ Population Sample } & \multicolumn{4}{|c|}{ Restriction Imposed } \\
\hline & $\begin{array}{l}\text { None: May Perform } \\
\text { In-depth Searching } \\
(\%)\end{array}$ & $\begin{array}{c}\text { Perform Ready } \\
\text { Reference Searching } \\
\text { Only } \\
(\%)\end{array}$ & $\begin{array}{c}\text { Other } \\
(\%)\end{array}$ & $\begin{array}{l}\text { Not Permitted to } \\
\text { Search } \\
(\%)\end{array}$ \\
\hline \multicolumn{5}{|l|}{$\begin{array}{l}\text { Carnegie } \\
\text { Classification }\end{array}$} \\
\hline $\begin{array}{r}\text { Research/doc- } \\
\text { toral }(\mathrm{N}=22)\end{array}$ & 18 & 27 & 0 & 55 \\
\hline $\begin{array}{l}\text { Comprehensive } \\
\text { university } \\
(\mathrm{N}=85)\end{array}$ & 6 & 11 & 1 & 82 \\
\hline $\begin{array}{l}\text { Liberal arts } \\
\qquad(\mathrm{N}=86)\end{array}$ & 9 & 10 & 7 & 73 \\
\hline $\begin{array}{l}\text { Two-year } \\
(N=157)\end{array}$ & 3 & 8 & 6 & 83 \\
\hline Total $(\mathrm{N}=350)$ & 6 & 10 & 5 & 79 \\
\hline$A R L(N=77)$ & 12 & 27 & 5 & 56 \\
\hline \multicolumn{5}{|l|}{ Gender } \\
\hline $\begin{array}{l}\text { Female } \\
\qquad(N=210)\end{array}$ & 4 & 9 & 4 & 83 \\
\hline Male $(\mathrm{N}=77)$ & 9 & 16 & 6 & 69 \\
\hline
\end{tabular}

professionals employed, they indicate that $74 \%$ of all paraprofessionals in the sample work in libraries in which at least some paraprofessionals are regularly assigned to the reference or information desks. All paraprofessionals in these libraries, therefore, are at least theoretically eligible to work at reference desks.

Twenty-one percent of the responding Carnegie and $44 \%$ of the ARL sample libraries report regularly scheduling paraprofessionals to perform DIALOG, BRS, Orbit, or similar online database searches. Some libraries in both groups impose restrictions upon some of these paraprofessional database searchers, for example, limiting them to ready reference searching only. The utilization of paraprofessionals for online database searching, as well as their deployment at reference or information desks, is more likely to occur in the larger, rather than the smaller, sample libraries (see table 7).
When weighted by the total number of paraprofessionals, the Carnegie sample data indicate that $46 \%$ of all paraprofessionals in this group work in environments where at least some paraprofessionals are regularly assigned to perform online database searching.

Respondents were queried about the use of paraprofessionals to perform various other tasks, many of which have not been traditionally assigned to them. The data indicate that $92 \%$ of the responding ARL libraries regularly assign LC-input copy cataloging tasks to paraprofessionals, and $91 \%$ assign them utility member-input copy cataloging tasks. The corresponding percentages for Carnegie Classification respondents are 61 and 49.

Fifty-one percent of all ARL respondents regularly assign original descriptive cataloging, and $36 \%$ assign both subject analysis and classification to paraprofessionals. Considerably fewer Car- 
TABLE 8

VARIOUS TASKS REGULARLY ASSIGNED PARAPROFESSIONALS

\begin{tabular}{lcccc}
\hline & \multicolumn{4}{c}{ Population Samples } \\
\cline { 2 - 5 } Task & Total Carnegie Classification & No. & $(\%)$ Yes & ARL \\
\hline Tours of library & 40 & $(\mathrm{~N}=346)$ & 71 & $(\mathrm{~N}=76)$ \\
Formal instruction in library use & 14 & $(\mathrm{~N}=339)$ & 21 & $(\mathrm{~N}=75)$ \\
Online catalog instruction & 26 & $(\mathrm{~N}=329)$ & 67 & $(\mathrm{~N}=76)$ \\
CD-ROM instruction & 36 & $(\mathrm{~N}=337)$ & 53 & $(\mathrm{~N}=77)$ \\
Book selection & 23 & $(\mathrm{~N}=340)$ & 21 & $(\mathrm{~N}=75)$ \\
Collection development & 16 & $(\mathrm{~N}=338)$ & 19 & $(\mathrm{~N}=75)$ \\
Copy cataloging: LC input & 61 & $(\mathrm{~N}=342)$ & 92 & $(\mathrm{~N}=77)$ \\
Copy cataloging: Member input & 49 & $(\mathrm{~N}=341)$ & 91 & $(\mathrm{~N}=75)$ \\
Original cataloging: Descriptive & 23 & $(\mathrm{~N}=345)$ & 51 & $(\mathrm{~N}=75)$ \\
Original cataloging: Subject analysis & 16 & $(\mathrm{~N}=340)$ & 36 & $(\mathrm{~N}=76)$ \\
Original cataloging: Classification & 22 & $(\mathrm{~N}=340)$ & 36 & $(\mathrm{~N}=73)$ \\
\hline
\end{tabular}

negie sample libraries assign these original cataloging duties to paraprofessionals, with $23 \%$ assigning descriptive, $16 \%$ assigning subject analysis, and $22 \%$ assigning classification duties.

Paraprofessionals are regularly assigned to lead tours of the library by $71 \%$ of the ARL and $40 \%$ of the Carnegie sample respondents. They are assigned formal instruction in library use by $21 \%$ of the ARL and $14 \%$ of the Carnegie respondents; online catalog instruction by $67 \%$ of the ARL and $26 \%$ of the Carnegie respondents; and CD-ROM instruction by $53 \%$ of the ARL and $36 \%$ of the Carnegie respondents. Book selection and collection development duties are regularly assigned to paraprofessionals by 21 and $19 \%$ of the ARL respondents respectively and by 23 and $16 \%$ of the Carnegie Classification respondents (see table 8).

\section{Administration and Governance}

Size of library is a factor in the level of administrative responsibility accorded paraprofessionals. Respondents were asked if paraprofessionals in their libraries have assumed substantial administrative responsibility in eleven functional areas, for example, budget formulation and training, supervision, and evaluation of full-time staff. In all of these areas, the ARL respon- dents report assigning more administrative responsibility to paraprofessionals than the Carnegie sample respondents.

Fifty-one percent of all ARL respondents regularly assign original descriptive cataloging, and $36 \%$ assign both subject analysis and classification to paraprofessionals.

Paraprofessionals are most frequently assigned substantial administrative responsibility in circulation $(84 \%$ in the ARL and $46 \%$ in the Carnegie sample libraries); next in acquisitions (71\%, ARL; 27\%, Carnegie); then in periodicals (66\%, ARL; 33\%, Carnegie); cataloging (64\%, ARL; $22 \%$, Carnegie); serials (63\%, ARL; 24\%, Carnegie); and interlibrary loan (58\%, ARL; 30\%, Carnegie).

The ARL respondents are also more likely to assign substantial administrative responsibility to paraprofessionals in branch units, documents, special collections, and archives than are Carnegie respondents. Comparisons based on size may be biased, however, by the fact that larger libraries are more likely than smaller ones to offer these particular collections and services (see table 9). 
TABLE 9

LIBRARIES THAT REGULARLY ASSIGN PARAPROFESSIONALS SUBSTANTIAL ADMINISTRATIVE RESPONSIBILITY IN VARIOUS FUNCTIONAL AREAS

\begin{tabular}{lcccc}
\hline & \multicolumn{4}{c}{ Population Samples } \\
\cline { 2 - 5 } Area of Responsibility & Total Carnegie Classification & \multicolumn{3}{c}{ ARL } \\
\hline Circulation & $(\%)$ Yes & No. & $(\%)$ Yes & No. \\
Interlibrary loan & 46 & $(\mathrm{~N}=346)$ & 84 & $(\mathrm{~N}=75)$ \\
Periodicals & 30 & $(\mathrm{~N}=342)$ & 58 & $(\mathrm{~N}=74)$ \\
Acquisitions & 33 & $(\mathrm{~N}=340)$ & 66 & $(\mathrm{~N}=73)$ \\
Serials & 27 & $(\mathrm{~N}=339)$ & 71 & $(\mathrm{~N}=75)$ \\
Cataloging & 24 & $(\mathrm{~N}=334)$ & 63 & $(\mathrm{~N}=73)$ \\
Branch units & 22 & $(\mathrm{~N}=332)$ & 64 & $(\mathrm{~N}=74)$ \\
Documents & 9 & $(\mathrm{~N}=318)$ & 55 & $(\mathrm{~N}=69)$ \\
Special collections & 13 & $(\mathrm{~N}=328)$ & 38 & $(\mathrm{~N}=68)$ \\
Archives & 10 & $(\mathrm{~N}=326)$ & 37 & $(\mathrm{~N}=70)$ \\
Other & 11 & $(\mathrm{~N}=319)$ & 24 & $(\mathrm{~N}=63)$ \\
\hline & 14 & $(\mathrm{~N}=175)$ & 53 & $(\mathrm{~N}=19)$ \\
\hline
\end{tabular}

TABLE 10

LEVEL OF PARAPROFESSIONAL INVOLVEMENT IN LIBRARY GOVERNANCE

\begin{tabular}{lccccc}
\hline & \multicolumn{5}{c}{ Level of Involvement } \\
\cline { 2 - 6 } & $\begin{array}{c}\text { Very } \\
\text { Substantial } \\
(\%)\end{array}$ & $\begin{array}{c}\text { Substantial } \\
(\%)\end{array}$ & $\begin{array}{c}\text { Some } \\
(\%)\end{array}$ & $\begin{array}{c}\text { Little } \\
(\%)\end{array}$ & $\begin{array}{c}\text { None } \\
(\%)\end{array}$ \\
\hline $\begin{array}{l}\text { Potal Carnegie Classification } \\
(N=354)\end{array}$ & 12 & 26 & 45 & 13 & 3 \\
$\begin{array}{l}\text { ARL }(N=77) \\
\text { Gender }\end{array}$ & 1 & 18 & 60 & 21 & 0 \\
$\quad$ Female $(\mathrm{N}=210)$ & 14 & 28 & 39 & 15 & 4 \\
$\quad$ Male $(\mathrm{N}=77)$ & 12 & 30 & 48 & 8 & 3 \\
\hline
\end{tabular}

Respondents were asked to characterize the level of involvement of paraprofessionals in the governance, policy formulation, planning and other administrative functions of their libraries. Thirtyeight percent of the Carnegie Classification respondents characterize this involvement as substantial or very substantial. Forty-five percent report some paraprofessional involvement. The corresponding percentages for the ARL sample respondents are somewhat lower at 19 and 60 percent respectively.

The differences in the responses of the Carnegie Classification and the ARL respondents indicate a degree of correlation with the size of the libraries. For example, the smaller liberal arts colleges and the two-year community, junior, and technical colleges report more involvement at the level characterized as very substantial (see table 10).

\section{Working Conditions}

Eighty-seven percent of all responding ARL libraries have ranked classification systems, or career ladders, that differentiate paraprofessional jobs by level of responsibility. When these responses are weighted by the total number of paraprofessionals, the data indicate that these libraries employ $91 \%$ of all paraprofessionals in the ARL sample. The Carnegie Classification data indicate 
TABLE 11

\section{LIBRARIES WITH RANKED CLASSIFICATION SYSTEMS THAT DIFFERENTIATE PARAPROFESSIONALS BY LEVELS OF RESPONSIBILITY}

Institutional Response

Response Weighted by No. of Paraprofessionals

Population Sample

(\%) Yes

(\%) Yes

Carnegie Classification

Research/doctoral $(\mathrm{N}=27)$

85

94

Comprehensive university $(\mathrm{N}=85)$

58

76

Liberal arts $(\mathrm{N}=86)$

23

43

Two-year $(\mathrm{N}=157)$

44

67

Total $(\mathrm{N}=355)$

45

78

Type of Control

Public ( $\mathrm{N}=222)$

Private $(\mathrm{N}=133)$

$A R L(N=77)$

Type of Control

Public

Private

Gender

Female $(\mathrm{N}=210)$

Male $(\mathrm{N}=77)$

"These data were weighted by the number of paraprofessionals at each responding library.

that $45 \%$ of the libraries in this sample have ranked classification systems; however, this $45 \%$ employs $78 \%$ of all of the paraprofessionals in this same sample. The Carnegie Classification category with the fewest ranked classification systems is the liberal arts colleges with $23 \%$.

In general, the survey results reveal few differences in the responses of private and public institutions. A few important variations, however, were recorded. For example, more than half $(59 \%)$ of the publicly supported institutions have ranked classification systems for their paraprofessionals. But this is true for less than one-fourth $(21 \%)$ of the libraries in private institutions (see table 11).

Ninety-one percent of all responding ARL libraries report some overlap between professional and paraprofessional salaries. Salary overlap indicates that a library pays at least some of its paraprofessionals wages comparable to or higher than those of entry-level librarians. The corresponding figure for the Carnegie sample libraries drops to $30 \%$. Within the Carnegie sample, $14 \%$ of the responding liberal arts college libraries and $23 \%$ of the responding two-year community, junior, and technical college libraries report salary overlap between the two groups (see table 12).

Most institutions use comparisons with other employee groups as criteria in the determination of paraprofessional salaries. The data indicate that a high percentage of both samples- $83 \%$ of the Carnegie Classification and $78 \%$ of the ARL respondents-use other support staff salaries on campus as a comparison criterion. Less frequently cited criteria are salaries for equivalent jobs in libraries at other institutions $(41 \%$, Carnegie; $47 \%$, ARL); librarians' salaries at the same institution (14\%, Carnegie; $8 \%, \mathrm{ARL}$ ); and other government employees' salaries as mandated by the state (22\%, Carnegie; 
TABLE 12

LIBRARIES REPORTING SALARY

OVERLAP BETWEEN

PARAPROFESSIONALS AND

LIBRARIANS

\begin{tabular}{lcc}
\hline & \multicolumn{2}{c}{ Response } \\
\cline { 2 - 3 } Population Sample & $\begin{array}{c}\text { Some } \\
\text { Overlap } \\
(\%)\end{array}$ & $\begin{array}{c}\text { No } \\
\text { Overlap } \\
(\%)\end{array}$ \\
\hline $\begin{array}{l}\text { Total Carnegie } \\
\text { Classification }(N=350)\end{array}$ & 30 & 70 \\
ARL $(N=77)$ & 91 & 9 \\
Gender & & \\
$\quad$ Female $(\mathrm{N}=208)$ & 22 & 78 \\
$\quad$ Male $(\mathrm{N}=76)$ & 41 & 59 \\
\hline
\end{tabular}

$40 \%, A R L)$. Twenty-four percent of the Carnegie and $45 \%$ of the ARL sample respondents report that salaries are established through collective bargaining negotiations (see table 13).

The ARL sample are more likely than the Carnegie sample libraries to make various incentives available to paraprofessionals.

The privately controlled institutions are more likely than the publicly supported ones to refer to other campus support staff categories (91\% versus $77 \%$ ) or librarians at the same institution (19\% ver- sus $10 \%$ ) in determining paraprofessional salaries. Private institutions, however, are less likely to make comparisons with equivalent jobs at other institutions ( $34 \%$ versus $46 \%$ ) or to arrive at salary determinations through collective bargaining negotiations (9\% versus $32 \%$ ) than are publicly supported ones.

\section{Staff Development}

Respondents were queried about staff development incentives offered all paraprofessionals and incentives offered only those seeking to acquire the M.L.S. In both cases, the ARL sample libraries are more likely than the Carnegie sample libraries to make various incentives available to paraprofessionals. For example, $84 \%$ of the Carnegie respondents offer orientation to new staff members, and $78 \%$ offer workshops and other inhouse training programs. The corresponding percentages for the ARL libraries are $97 \%$ in both cases. Ninetysix percent of the ARL sample respondents offer released time and $87 \%$ funding to attend local, state, and regional meetings; the corresponding percentages for the Carnegie sample are 90 and 81 .

Released time to attend national meetings is offered to paraprofessionals by $68 \%$ of the ARL respondents, but by only $32 \%$ of the Carnegie Classification respondents. Funding to attend national

TABLE 13

COMPARISON CRITERIA USED TO DETERMINE PARAPROFESSIONAL SALARIES

\begin{tabular}{lcccc}
\hline & \multicolumn{4}{c}{ Population Samples } \\
\cline { 2 - 5 } & Total Carnegie Classification & \multicolumn{2}{c}{ ARL } \\
Criteria & $(\%)$ Yes & No. & $(\%)$ Yes & No. \\
\hline $\begin{array}{l}\text { Other support staff salaries on campus } \\
\begin{array}{l}\text { Salaries of equivalent positions in libraries } \\
\text { at other institutions }\end{array}\end{array}$ & 83 & $(\mathrm{~N}=305)$ & 78 & $(\mathrm{~N}=65)$ \\
$\begin{array}{l}\text { Librarians' salaries at the same institution } \\
\begin{array}{l}\text { Other government employees' salaries as } \\
\text { mandated by the state }\end{array}\end{array}$ & 14 & $(\mathrm{~N}=259)$ & 8 & $(\mathrm{~N}=53)$ \\
$\begin{array}{l}\text { Salaries established through collective } \\
\text { bargaining negotiations }\end{array}$ & 22 & $(\mathrm{~N}=260)$ & 40 & $(\mathrm{~N}=55)$ \\
\begin{tabular}{l} 
Other \\
\hline
\end{tabular} & 24 & $(\mathrm{~N}=274)$ & 45 & $(\mathrm{~N}=66)$ \\
\end{tabular}


TABLE 14

STAFF DEVELOPMENT INCENTIVES OFFERED PARAPROFESSIONALS

\begin{tabular}{|c|c|c|c|c|c|c|c|c|}
\hline \multirow[b]{3}{*}{ Incentive } & \multicolumn{4}{|c|}{ Population Samples } & \multicolumn{4}{|c|}{ Gender-based Samples } \\
\hline & \multicolumn{2}{|c|}{$\begin{array}{l}\text { Total Carnegie } \\
\text { Classification }\end{array}$} & \multicolumn{2}{|c|}{ ARL Sample } & \multicolumn{2}{|c|}{ Female } & \multicolumn{2}{|c|}{ Male } \\
\hline & $\%$ Yes & No. & $\%$ Yes & No. & $\%$ Yes & No. & $\%$ Yes & No. \\
\hline Orientation of new staff members & 84 & $(\mathrm{~N}=337)$ & 97 & $(\mathrm{~N}=75)$ & 82 & $(\mathrm{~N}=194)$ & 89 & $(\mathrm{~N}=75)$ \\
\hline $\begin{array}{l}\text { Workshops and other in-house } \\
\text { training programs }\end{array}$ & 78 & $(\mathrm{~N}=343)$ & 97 & $(\mathrm{~N}=76)$ & 74 & $(\mathrm{~N}=199)$ & 87 & $(\mathrm{~N}=76)$ \\
\hline $\begin{array}{l}\text { Released time to attend local, state, } \\
\text { and regional meetings }\end{array}$ & 90 & $(\mathrm{~N}=349)$ & 96 & $(\mathrm{~N}=77)$ & 90 & $(\mathrm{~N}=205)$ & 96 & $(\mathrm{~N}=76)$ \\
\hline $\begin{array}{l}\text { Released time to attend national } \\
\text { meetings }\end{array}$ & 32 & $(\mathrm{~N}=327)$ & 68 & $(\mathrm{~N}=77)$ & 24 & $(\mathrm{~N}=188)$ & 42 & $(\mathrm{~N}=74)$ \\
\hline $\begin{array}{l}\text { Funding to attend local, state, and } \\
\text { regional meetings }\end{array}$ & 81 & $(\mathrm{~N}=350)$ & 87 & $(\mathrm{~N}=76)$ & 78 & $(\mathrm{~N}=206)$ & 86 & $(\mathrm{~N}=76)$ \\
\hline $\begin{array}{l}\text { Funding to attend national } \\
\text { meetings }\end{array}$ & 24 & $(\mathrm{~N}=327)$ & 61 & $(\mathrm{~N}=75)$ & 18 & $(\mathrm{~N}=189)$ & 31 & $(\mathrm{~N}=74)$ \\
\hline Other & 21 & $(\mathrm{~N}=57)$ & 58 & $(\mathrm{~N}=12)$ & 14 & $(\mathrm{~N}=35)$ & 45 & $(\mathrm{~N}=11)$ \\
\hline
\end{tabular}

meetings is offered by $61 \%$ of the ARL, but only $24 \%$ of the Carnegie respondents (see table 14). The smaller Carnegie Classification category libraries are less likely to grant paraprofessionals released time and funding to attend national meetings than are their larger counterparts. For example, only $27 \%$ of the responding liberal arts colleges grant released time and $20 \%$ funding. The corresponding percentages for the two-year community, junior, and technical colleges are 30 and $22 \%$, and for the comprehensive colleges and universities, 31 and $26 \%$.

Libraries in private institutions are more likely than those in public institutions to grant released time for classes ( $53 \%$ versus $44 \%$ ), adjusted work schedules $(88 \%$ versus $77 \%)$, and preference for a professional position upon graduation ( $47 \%$ versus $23 \%$ ) to paraprofessionals who wish to acquire the M.L.S.

When respondents were queried about the incentives they offer paraprofessionals seeking an M.L.S., the ARL respondents were again found to be the more generous. For example, $51 \%$ of the ARL respondents offer paraprofessionals seeking an M.L.S. released time for classes, $91 \%$ offer adjusted work schedules, and $60 \%$ offer tuition remission or reimbursement. The corresponding percentages for the Carnegie sample respondents are 37,67 , and $33 \%$.

When respondents were asked if they would grant preference for reemployment in a professional position to former paraprofessionals upon graduation, however, only $9 \%$ of the ARL, compared with $24 \%$ of the Carnegie sample respondents, replied yes. With a $39 \%$ response rate, the liberal arts college libraries are the Carnegie Classification category most likely to reemploy in professional positions paraprofessionals who attain the M.L.S. (see table 15).

The differences in the responses of the two samples are highlighted when the Carnegie data are weighted by number of paraprofessionals. For example, only $24 \%$ of the Carnegie Classification respondents report that they would be willing to fund paraprofessional attendance at a national meeting. This $24 \%$, however, employs $40 \%$ of all paraprofessionals in the total Carnegie sample.

\section{Length of Employment}

The Carnegie respondents' estimates of the average length of employment of paraprofessionals are somewhat lower than those of the ARL respondents. For example, $33 \%$ of the Carnegie and $22 \%$ 


\section{TABLE 15}

INCENTIVES OFFERED PARAPROFESSIONALS SEEKING TO ACQUIRE AN M.L.S.

\begin{tabular}{|c|c|c|c|c|c|}
\hline \multirow[b]{2}{*}{ Population Sample } & \multicolumn{5}{|c|}{ Incentive } \\
\hline & $\begin{array}{c}\text { Released Time } \\
\text { for Classes } \\
(\%)\end{array}$ & $\begin{array}{c}\text { Adjusted } \\
\text { Work Schedule } \\
(\%)\end{array}$ & $\begin{array}{c}\text { Tuition } \\
\text { Remission or } \\
\text { Reimbursement } \\
(\%)\end{array}$ & $\begin{array}{c}\text { Preferential } \\
\text { Rehire in a } \\
\text { Professional } \\
\text { Position upon } \\
\text { Graduation } \\
(\%)\end{array}$ & $\begin{array}{c}\text { Other } \\
(\%)\end{array}$ \\
\hline \multicolumn{6}{|l|}{ Carnegie Classification } \\
\hline $\begin{array}{l}\text { Research/doctoral } \\
(\mathrm{N}=27)\end{array}$ & 56 & 96 & - 56 & 15 & 4 \\
\hline $\begin{array}{l}\text { Comprehensive } \\
\text { university }(\mathrm{N}=90)\end{array}$ & 36 & 74 & 36 & 24 & 6 \\
\hline Liberal arts $(\mathrm{N}=89)$ & 51 & 79 & 22 & 39 & 6 \\
\hline Two-year $(\mathrm{N}=184)$ & 28 & 53 & 33 & 17 & 4 \\
\hline Total $(\mathrm{N}=390)$ & 37 & 67 & 33 & 24 & 5 \\
\hline$A R L(N=77)$ & 51 & 91 & 60 & 9 & 5 \\
\hline \multicolumn{6}{|l|}{ Gender } \\
\hline Female $(\mathrm{N}=170)$ & 47 & 74 & 39 & 32 & 20 \\
\hline Male $(\mathrm{N}=65)$ & 47 & 88 & 36 & 39 & 43 \\
\hline
\end{tabular}

TABLE 16

AVERAGE LENGTH OF EMPLOYMENT OF PARAPROFESSIONALS

\begin{tabular}{lcccc}
\hline & \multicolumn{4}{c}{ Years of Employment } \\
\cline { 2 - 5 } Population Sample & $\begin{array}{c}0-1 \\
(\%)\end{array}$ & $\begin{array}{c}2-5 \\
(\%)\end{array}$ & $\begin{array}{c}6-10 \\
(\%)\end{array}$ & $\begin{array}{c}11 \text { or More } \\
(\%)\end{array}$ \\
\hline $\begin{array}{l}\text { Carnegie Classification }(N=350) \\
\text { ARL }(N=77)\end{array}$ & 1 & 33 & 39 & 26 \\
Gender & 0 & 22 & 58 & 19 \\
$\quad$ Female $(\mathrm{N}=207)$ & 1 & 35 & 33 & 31 \\
$\quad$ Male $(\mathrm{N}=76)$ & 1 & 38 & 41 & 20 \\
\hline
\end{tabular}

of the ARL respondents estimate the average length of paraprofessional employment to be 2 to 5 years. Twenty-six percent of the Carnegie and 19\% of the ARL respondents estimate the average length of paraprofessional employment to be 11 or more years (see table 16).

\section{Gender Perspective}

Results based on gender were arrived at by sorting all Carnegie Classification responses into male and female samples. The female sample includes the data from 211 libraries reporting all-female paraprofessional staffs. The male sample includes the data from 77 libraries re- porting a male-to-female ratio of $1: 4$ or more. The male sample is referred to as "a considerable male paraprofessional presence" and the female sample as "allfemale paraprofessional staff members."

The data derived from these genderbased sorts reveal that the reward structures and working conditions for all paraprofessionals are better in libraries where this cohort includes a high or relatively high proportion of males. For example, $41 \%$ of all Carnegie Classification libraries with a considerable male paraprofessional presence report some salary overlap between paraprofessionals and librarians, but at libraries with all-female 
paraprofessional staffs that figure declines to $22 \%$ (see table 12 ). Forty-seven percent of the responding libraries with a considerable male paraprofessional presence offer a ranked classification system, or career ladder, for all paraprofessionals. This holds true, however, for only $38 \%$ of the reporting libraries with all-female paraprofessional staffs (see table 11).

More libraries with a considerable male paraprofessional presence report regularly assigning paraprofessionals tasks traditionally performed by librarians than do libraries reporting all-female paraprofessional staffs. For example, $82 \%$ of the responding libraries with a considerable male paraprofessional presence regularly schedule paraprofessionals to work at the reference desk, but this holds true for only $65 \%$ of those with all-female paraprofessional staffs. Also, fewer restrictions are imposed upon paraprofessionals performing these tasks in libraries with a considerable male paraprofessional presence (see table 6).

This gender-related differential remains constant in sample libraries that regularly schedule paraprofessionals to perform DIALOG, BRS, or Orbit searching of remote online databases. Thirty-one percent of the responding libraries with a considerable male paraprofessional presence regularly schedule paraprofessionals to perform this task, while only $17 \%$ of those with all-female paraprofessional staffs do (see table 7).

The data also indicate that there is a slightly higher level of support for staff development activities in responding libraries with a considerable male paraprofessional presence. This difference is most apparent in the level of support granted for attending national conferences. Of those libraries reporting a considerable male paraprofessional presence, $42 \%$ offer released time and $31 \%$ offer funding to paraprofessionals who wish to attend national workshops or conferences. The corresponding percentages for libraries with all-female paraprofessional staffs drop to 24 and $18 \%$ respectively (see table 14). No major gender differences were found, however, in the level of support for paraprofessionals seeking to ac- quire an M.L.S. Released time, adjusted work schedules, and tuition remission or reimbursement are granted both groups in approximately equal measure (see table 15).

The educational level of paraprofessionals is reported by the director-respondents to be higher in libraries with a considerable male paraprofessional presence. Seventyfive percent report that they employ some paraprofessionals who hold a degree higher than that required for the job. Of those libraries with all-female paraprofessional staffs, that estimate declines to $55 \%$ (see table 4 ).

\section{The working conditions for all para- professionals are better in libraries where this cohort includes a high or relatively high proportion of males.}

Turnover among paraprofessionals is somewhat higher in responding libraries whose staffs include a considerable male paraprofessional presence. Only 20\% of these institutions report the average length of employment to be more than 10 years, while the figure for libraries with all-female paraprofessional staffs is $31 \%$ (see table 16). At the same time, no meaningful differences in the perceived levels of involvement of paraprofessionals in the governance of their libraries are found between these two subject groups. Fortytwo percent of each group of respondents report substantial or very substantial paraprofessional involvement (see table 10).

\section{DISCUSSION}

The collective portrait of paraprofessionals that emerges from this survey is that of a vital, growing force within academic libraries. Few traditional or newly created tasks are off-limits, and paraprofessionals are routinely assigned complex duties that a generation ago characterized the work of librarians. Paraprofessionals are better off in large research libraries than they are in small college libraries and better off when the staff includes a considerable number of males. In many cases, the data confirm widely held im- 
pressions that until now were supported by anecdotal evidence only.

Many of the respondents report not only employing more paraprofessionals today than in the past, but fewer librarians as well. Most paraprofessionals are female. The large libraries are characterized by a higher ratio of paraprofessionals to librarians and a higher ratio of male-to-female paraprofessionals than the smaller ones. The survey, however, was not designed to respond to the questions of whether library administrators are replacing professionals with paraprofessionals and, if they are, in what areas and for what reasons. These questions deserve closer scrutiny.

The collective portrait of paraprofessionals that emerges from this survey is that of a vital, growing force within academic libraries.

As a group, paraprofessionals tend to be better qualified than their job descriptions require them to be. The ARL and the other large research libraries have higher formal degree requirements than do the smaller libraries. This trend may reflect both availability and the more specialized staffing needs of the larger libraries. Overqualification likely contributes to task overlap between librarians and paraprofessionals.

Why paraprofessionals often are overqualified warrants investigation. Overqualification may result from the prolonged slowdown of the economy and the general contraction of higher education in the United States. Poor job design, poor task assignment, restrictions on mobility, or simply the fact that educated candidates find library jobs to be intellectually appealing no doubt contribute. Newly minted liberal arts graduates who lack marketable job skills may be attracted to the service role of the library, the prestige of the academy, and the high level of tolerance for cultural diversity and nonconformity found on campuses.

There is also the possibility that librarians seek out applicants with qualifica- tions higher than what their institutions permit them to require. In college libraries, for example, the librarian's right to require a bachelor's degree can be challenged by campus administrators who prefer to keep library jobs in line with other campus jobs that do not require the B.A.

Many high-level skills are demanded of paraprofessionals. Tasks that in the past were the exclusive preserve of librarians are now routinely assigned to paraprofessionals. In a majority of all academic libraries, for example, paraprofessionals are regularly scheduled to work at reference and information desks. ${ }^{35}$ A surprisingly high number are regularly scheduled to perform online database searches. Although restrictions are placed upon their performance in relatively few libraries, the long-standing debate over whether paraprofessionals should be used at reference desks appears to be resolved, at least in practice. Here again, large libraries are more likely than small ones to use paraprofessionals for this task, possibly because these large schools have lower librarian-to-student ratios.

How successfully paraprofessionals perform at the reference desk has been a concern of library researchers for many years. The question of why significant numbers of paraprofessionals have been pressed into service at the reference desk, however, is less well researched and deserves further attention. On the one hand, it may be that as librarians assumed their new database-searching and faculty status-related obligations of governance, research, and teaching, budget constraints kept them from hiring enough additional librarians to staff the desk exclusively with professionals. On the other hand, the increased use of paraprofessionals at the reference desk may reflect the fledgling trend toward the division of reference work into its two logical components, information provision and research support.

In both technical and public services, paraprofessionals are routinely assigned tasks that in the past they were rarely if ever allowed to perform. An important issue that future studies should investi- 
gate is whether paraprofessionals are being assigned levels of responsibility higher than what is required by their classification. Today, paraprofessionals perform copy cataloging in a majority of all academic libraries. A considerable number of the ARL libraries assign paraprofessionals original cataloging as well. Fewer Carnegie Classification libraries assign original cataloging tasks to paraprofessionals, but this difference may simply reflect the fact that less original cataloging is performed at the smaller libraries. More surprisingly, approximately one-fifth of all academic libraries surveyed assign book selection and collection development duties to paraprofessionals. The figure is somewhat higher than the 10 to $11 \%$ of the library assistants whom Patricia A. Kreitz and Annegret Ogden found to be engaged in collection building at the University of California. ${ }^{36}$

The data indicate that considerably more administrative responsibility for various functional areas is invested in paraprofessionals by the ARL than by the smaller Carnegie Classification libraries. At the same time, Carnegie library respondents report paraprofessionals to be more deeply involved in library governance than do their ARL counterparts. Of course, the sheer size of the larger institutions may preclude the level of involvement that can be achieved at the smaller ones.

One measure of the recognition accorded support staff is whether a career ladder, or ranked classification system, is made available to them. Here, size of institution plays a clear role. Almost $90 \%$ of the ARL respondents report career ladders for paraprofessionals, a figure that varies little by type of institutional control. This percentage drops precipitously in the smaller institutions.

Traditional wisdom holds that career ladders are confined to larger libraries because little opportunity for advancement predicated on specialization or added supervisory responsibility exists in the smaller ones. It is not clear, however, that this argument can be maintained in a period of rapid change and technologi- cal innovation. It is probable, however, that a higher degree of unionization in the larger libraries accounts for at least some of this difference. In the liberal arts college libraries, the lack of a career ladder may be attributed to the gentlemen's agreement that is presumed to exist between employees and administration and its logical outgrowth, an honor system in which careers are codified with a handshake rather than a contract.

\section{Tasks that in the past were the exclusive preserve of librarians are now routinely assigned to para- professionals.}

The same polarization of response by size of library was recorded when directors of large and small institutions were asked if salary overlap exists between paraprofessionals and librarians. Here as well, larger libraries are more likely than smaller ones to report such overlap. Unionization may play a role. It would be interesting to compare salaries in schools at which the paraprofessionals are unionized and the librarians are not, with salaries at schools where the reverse is true.

The determination of paraprofessional salaries at both large and small libraries appears to depend heavily upon job comparisons with other support staff on the local campuses. The responses received raise doubts about whether librarians have communicated effectively to campus administrators and personnel officers the magnitude of the changes that have occurred in paraprofessional jobs. Campus personnel officers hold considerable power, yet often know little about what goes on in a library. Research focused in this area should aim at determining if these comparisons are being made with appropriate nonlibrary support staff jobs. Clearly, inappropriate comparisons of library paraprofessional jobs with unrelated clerical jobs in food services, physical plant, and business or departmental offices would degrade library paraprofessional salaries and status. 
A high percentage of the respondents offer a variety of staff development incentives to paraprofessionals, although the number dips sharply when higher levels of funding are involved, for example, attendance at national meetings. As more paraprofessionals begin to speak and act at the national level, funding will assume greater importance to them. Because it is likely that librarian advancement is more directly correlated to attendance and participation than support staff advancement, however, travel funds for paraprofessionals should not be in competition with those for professionals.

The ARL libraries are somewhat more likely than the Carnegie sample libraries to offer certain staff development incentives, although the differences are not great. The data do not, however, address the question of how equitably travel funding is distributed, nor whether paraprofessionals are encouraged to apply for it or are even informed that it is available. In fact, several respondents noted that they would, indeed, grant travel support to paraprofessionals were it requested, but added that none had yet come forth to apply.

The large libraries offer more incentives than the smaller ones for paraprofessionals seeking to acquire the M.L.S., yet they are much less likely than their smaller counterparts to reemploy paraprofessionals in professional positions upon graduation. Whether libraries should rehire as professionals support staff who attain the M.L.S. bears directly upon the pattern of education librarianship should provide. A discussion of whether the abrupt rupture of forced relocation is an appropriate entry requirement into the profession would be useful. Another phenomenon that should be investigated is the effect of hiring candidates with graduate library degrees into paraprofessional positions.

In sum, the data indicate that the ARL libraries expect more, pay more, offer more tangible benefits, employ more males, and have a higher rate of paraprofessional turnover than do the smaller Carnegie Classification libraries. Librarians in smaller libraries may wish to emu- late some of the practices of their counterparts in the larger institutions, but it is doubtful that the larger institutions constitute a definitive model. Progress towards equity in the ARL libraries remains slow.

Although the large libraries have more clearly defined benefits and expectations, it is often suggested that the smaller ones, particularly those at the liberal arts colleges, have more informal flexibility, offer deeper involvement in the life of the library and the campus, and provide more intangible rewards. ${ }^{37}$ Small liberal arts college libraries also have captive applicant pools populated to an unknown degree by faculty and student spouses and those seeking tuition remission for themselves or their dependents. Further, better job opportunities no doubt exist in the larger metropolitan areas where many ARL libraries are located.

Perhaps not unexpectedly, the data indicate that all paraprofessionals are better off in libraries that employ a considerable number of males. The more males there are on the paraprofessional staff, the higher the salaries relative to the salaries of librarians, the higher the level of involvement in administrative decision making, the more likely it is that paraprofessionals are allowed to work at the reference desk and perform online database searching, and the better their chances of obtaining released time and funding to attend national conferences.

The implications of these data are selfevident for such issues as occupational segregation, pay equity, and comparable worth. These data also tend to confirm that paraprofessionals as well as librarians suffer the effects of working within a majority-female profession and the effects of female socialization into passive roles. ${ }^{38}$ The remarkable ability of librarians to deny these problems should not, however, be allowed to hinder research in this area. ${ }^{39}$

At the same time, numerous forces are changing profoundly the nature of library work. Two changes in particular, increased automation and the growing 
intellectualization of the field, hold promise of improving the status of all who work within librarianship. ${ }^{40}$ Both computers and intellectual work are traditionally associated with majority-male professions. Their more recent association with libraries can contribute to changing the generalized perception of librarianship as woman's work. This change should enhance the status of the profession and give both women and men in libraries a greater sense of empowerment.

\section{CONCLUSIONS}

The results of this survey can be interpreted as a mandate to the profession to define less ambiguously the role, status, and working conditions of librarians and paraprofessionals alike. The rapid changes occurring in the library workplace underscore the need for continuing local and national review of the deployment and utilization of all library staff. The emergence of paraprofessionals as a distinct class of library employee, the dangerously broad band of task overlap between paraprofessionals and librarians, and the failure of leadership and vision within the profession pose severe problems.
The resolution of these problems requires the development of standards, guidelines, and other policy statements that address such primary concerns as staff structures, classification systems, basic and continuing education, and educational degree and certification requirements. The coping mechanisms adopted by other majority-female professions, for example, nursing and teaching, should be examined closely. At the national level, librarians need to create model staff development programs that can be replicated locally and define productive roles and appropriate membership categories for paraprofessionals within their professional associations.

Librarianship will certainly fail to attain full professional status unless librarians come to grips with the problems that inhere in poor staff deployment, task overlap, role blurring, and their passive acceptance of the profession as sextyped. Unfortunately, librarians shy away from and even deny these problems. A lack of collective self-esteem, however, must not prevent the resolution of this staffing dilemma, a dilemma that is nothing less than a metaphor for a profession at the crossroads.

\section{REFERENCES AND NOTES}

1. Paraprofessionals are generally defined as a category of employee that ranks above clerks and below professionals in a status hierarchy. See note 30 for the definition of paraprofessionals used in this survey.

2. Oberg discusses the effects of task overlap and role blurring in the workplace and the profession in Larry R. Oberg, "The Emergence of the Paraprofessional in Academic Libraries: Perceptions and Realities," College \& Research Libraries 53:99-112 (Mar. 1992).

3. American Library Association, Library Education and Personnel Utilization (Chicago: American Library Assn., 1976). LEPU was originally promulgated in 1970 as Library Education and Manpower

4. The need for a new model of librarianship to define less ambiguously the roles of all players is discussed in Oberg, "The Emergence of the Paraprofessional," p. 108-9.

5. Although the data would support more rigorous statistical analysis, additional manipulation was considered beyond the scope of the present effort. A second paper, focusing on several aspects of paraprofessionalism that the authors feel would profit from further examination, may appear at a later date.

6. J. Keith Ostertag, "Annotated Bibliography," in J. Keith Ostertag and Kathleen M. Heim, eds., Library Support Staff: Challenges for the 90s (Chicago: American Library Assn., Office for Library Personnel Resources, 1992).

7. Charlotte Mugnier, The Paraprofessional and the Professional Job Structure (Chicago: American Library Assn., 1980).

8. Charles W. Evans, "The Evolution of Paraprofessional Library Employees," in Advances in Librarianship v.9 (New York: Academic, 1978), p.64-101. 
9. Olga B. Bishop, The Use of Professional Staff in Libraries: A Review 1923-1971 (Ottawa: Canadian Library Assn., 1973).

10. Lester Asheim, "Education and Manpower for Librarianship: A Position Paper Suggesting First Steps Toward a Statement of Policy," ALA Bulletin 62:1096-1106 (Oct. 1968).

11. Charles A. Bunge, Professional Education and Reference Efficiency (Springfield, Ill.: Illinois State Library, 1967).

12. Louis Shores, "Library Technician: A Professional Opportunity," Special Libraries 59:240-45 (Apr. 1968).

13. Leo Nelson Flanagan, "A Sleeping Giant Awakens: The Unionization of Library Support Staffs," Wilson Library Bulletin 48:491-99 (Feb. 1974).

14. Ralph M. Edwards, "The Management of Libraries and the Professional Functions of Librarians," Library Quarterly 45:150-60 (Apr. 1975).

15. Margaret Myers, "Staffing Patterns," in Sheila Creth and Frederick Duda, Personnel Administration in Libraries, 2d ed. (New York: Neal-Schuman, 1989), p.40-63.

16. Charles Martell, "Improving the Effectiveness of Libraries through Improvements in the Quality of Working Life," College \& Research Libraries 42:435-46 (Sept. 1981).

17. Robert E. Molyneux, "Staffing Patterns and Library Growth at ARL Libraries, 1962/63 to 1983/84," Journal of Academic Librarianship 12:292-97 (Nov. 1986).

18. Allen B. Veaner, "Continuity or Discontinuity-A Persistent Personnel Issue in Academic Librarianship," Advances in Library Administration \& Organization 1:1-20 (1982).

19. Allen B. Veaner, "1985 to 1995: The Next Decade in Academic Librarianship, Part I," College \& Research Libraries 46:209-29 (May 1985), and Allen B. Veaner, "1985 to 1995: The Next Decade in Academic Librarianship, Part II," College \& Research Libraries 46:295-308 (July 1985).

20. Joanne R. Euster, "Changing Staffing Patterns in Academic Libraries," Library Issues 7:[1]-[3] (Sept. 1986).

21. Kathleen M. Heim and Debbie Wolcott, with the assistance of Ed McCormack, "Staff Utilization in Libraries: The Historical and Environmental Context for Renewed Attention to Education, Role Definition, and Articulation with Special Consideration of Medicine and Law," Louisiana Library Association Bulletin 52:149-58 (Spring 1990).

22. Oberg, "The Emergence of the Paraprofessional."

23. John Levett, "Paraprofessional Workers in Four Fields: A Comparative Study," The Australian Library Journal 30:47-54 (May 1981).

24. Ian M. Johnson, "The Development of Library Technicians: A Review of Experience in Selected Countries," IFLA General Conference, 1990, Booklet 3 (The Hague, 1990; Bethesda, Md.: ERIC Document Reproduction Service, ED 329 284), p.53-61.

25. Brian A. Nettlefold, "Paraprofessionalism in Librarianship," International Library Review 21:519-31 (1989).

26. Karen Beales, "Non-professional Information and Training," Education for Information 7:29-41 (1989).

27. Donald E. Davinson, "Non-professional Library Staff Education: A State of the Art Report and Proposals for the Future," in Studies in Library Management, v.7 (London: Bingley, 1982), p.37-60.

28. Josephine Webb, "The Non-professional in the Academic Library: Education for Paraprofessionalism," Personnel Training and Education 7:21-30 (1990).

29. Helen Smeaton, "Library Technicians in Australia: Past, Present and Future," Australasian College Libraries 1:34-37 (May 1983).

30. The lack of an unambiguous shared definition of the term paraprofessional is vexing. The description of paraprofessionals that the authors used in their questionnaire is based upon American Library Association and Integrated Postsecondary Education Data System (IPEDS) definitions. It lists positions characteristic of the class as well as uncharacteristic positions that respondents were instructed to exclude. A number of respondents were nonetheless confused by or critical of the term. Some report that higher-level support staff consider themselves to be support professionals, not paraprofessionals. A few others suggest that they consider all support staff to be clerical. Some respondents found it difficult to draw the line between clerical and paraprofessional employees or between paraprofessionals and librarians. Others were 
confused because the term has not been officially sanctioned at their institutions or because it is interpreted differently within their local context. Clearly, the lack of a less ambiguous shared definition of the term paraprofessional is a factor that can limit research.The definition used in the survey is as follows. "Paraprofessionals: The term paraprofessional designates library positions with entrance-level requirements that are distinctly different from those of librarians. Paraprofessionals are assigned high level support responsibilities in positions whose tasks are specific to libraries. They commonly perform their duties with some supervision by a librarian. The term is often applied to personnel classified as library assistants, associates, technicians, and technical assistants. Examples of paraprofessional position titles include: head of circulation, interlibrary loan assistant, acquisitions coordinator, catalog assistant, periodicals supervisor, reference assistant, etc.

Do not include as paraprofessionals: secretaries, typists, bookkeepers, and others whose positions require primarily office-related skills; student library assistants, photographers, photocopy room and mailroom employees, audiovisual technicians, etc.; or professionals who may not hold a master's degree in librarianship, for example: systems analysts, library business officers, library personnel officers, etc."

31. It is useful to note that the questionnaire was designed to be answered by library directors or their designees, not by paraprofessionals. Until a comprehensive directory exists, national surveys of paraprofessionals will be difficult, if not impossible, to conduct. In the meanwhile, surveys of the perceptions of paraprofessionals will continue to be limited to individual institutions, groups of like institutions, and states or regions. Although the lack of a national list can limit research possibilities, it was not a hinderance in this case because the questions were designed to elicit factual, not attitudinal, responses. For the same reason, it is unlikely that the questionnaires completed by designees rather than the director introduced bias into the responses.

32. Carnegie Foundation for the Advancement of Teaching, A Classification of Institutions of Higher Education, 1987 ed. (Princeton, N.J.: Carnegie Foundation for the Advancement of Teaching, 1987).

33. The Carnegie Classification of institutions of higher education groups U.S. colleges and universities by mission and function. Two categories of doctorate-granting institutions are used by Carnegie: research universities and doctorate-granting colleges and universities. Institutions that do not grant degrees through the doctoral level are categorized as comprehensive universities and colleges; liberal arts colleges; and two-year community, junior, and technical colleges. (Other categories of specialized institutions and professional schools exist, but were not included in this study.) All of the categories used in our survey except the two-year colleges are further subdivided by levels I and II. Although the Carnegie Foundation makes it clear that institutions are grouped by shared characteristics and that its aim is not to establish a hierarchy, the division by levels nonetheless separates the stronger institutions from the others.

34. Full data from the survey are held by Larry R. Oberg, director of libraries, StockwellMudd Libraries, Albion College, Albion, Mich. 49224-1879.

35. The figures from this survey (see table 6) are higher than those reported by Murfin in her review of earlier surveys. The authors found a $72 \%$ utilization rate for the liberal arts colleges and an $88 \%$ rate for the ARL libraries; Murfin cites three earlier surveys that report utilization rates ranging from 60 to 75\%. See Marjorie Murfin, "Trends in Use of Support Staff and Students at the Reference Desk in Academic Libraries," Library Personnel News 2:10 (Winter 1988).

36. Patricia A. Kreitz and Annegret Ogden, "Job Responsibilities and Job Satisfaction at the University of California Libraries," College \& Research Libraries 51:302-3 (July 1990).

37. See, for example, Larry Hardesty, "Life in the Minor Leagues; or, Crash Davis Finds Happiness" [guest editorial] College \& Research Libraries 51:397-98 (Sept. 1990).

38. Gorman notes that librarianship, "rooted as it is in the self-sacrificing 'Angel in the House' ethos characteristic of the majority-female professions, has in many ways betrayed itself by making a virtue of doing more with less, of 'pitching in' and 'scraping by."' When weinstitutionalize such behavior, hestates that it "may actually engender depreciation rather than respect." Gorman also suggests that "the search for professionalism" will be "one of 
the dominant themes of the future," closely linked with the rise of feminism. See Michael Gorman, "The Academic Library in the Year 2001: Dream or Nightmare or Something in Between?" Journal of Academic Librarianship 17:5, 8 (Mar. 1991); for a discussion of sex-segregated work and sexual stratification within librarianship, see Suzanne Hildenbrand, "The Crisis in Cataloging: A Feminist Hypothesis," in Sheila S. Intner and Janet Swan Hill, Recruiting, Educating, and Training Catalog Librarians: Solving the Problems (Westport, Conn.: Greenwood, 1989).

39. Janice J. Kirkland notes that the startling disparity within librarianship between level of compensation and position requirements is "more often met with acceptance than with analysis leading to action." Librarians, she suggests, use two cognitive techniques that "eliminate the need to protest." First, they reevaluate their rewards in a manner that allows them to include such nonmonetary compensation as environment, contacts with colleagues, and the ability to serve others; secondly, they circumscribe their analyses by comparing their pay to that of other majority-female professions, not to equivalent majority-male ones. See Janice J. Kirkland, "Equity and Entitlement: Internal Barriers to Improving the Pay of Academic Librarians," College \& Research Libraries 52:375-76 (July 1991).

40. Veaner notes that within a generation librarians "virtually ceased to be production workers" as they acquired greater responsibility for the programmatic aspects of their libraries. These new programmatic responsibilities, he points out, are abstract and intellectual and contrast sharply with production work measured in terms of output units. See Veaner, "Librarians: The Next Generation," Library Journal 109:623-25 (Apr. 1, 1984).

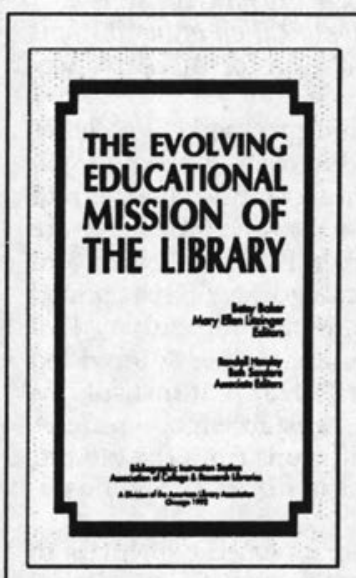

$\$ 29.95$

(\$19.95 for

ACRL members)

$202 \mathrm{pp}, 1992$

ISBN 0-8389-7584-4

Order Department

ALA Publishing Services

50 East Huron Street

Chicago, IL 60611

Or call toll-free

$1-800-545-2433$

Fax: 312-944-2641

\section{The Evolving} Educational Mission of the Library

\section{Betsy Baker and Mary Ellen Litzinger, Editors}

The Evolving Educational Mission of the Library provides a series of essays articulating ideas on information literacy in library user education, the information explosion impact on information organization and access in the curriculum, user demography creating new educational constituencies, and impact on changes in academic libraries on information science curricula.

Though not a direct result of the Bibliographic Instruction Section's Think Tank of June 22-23, 1989, these essays represent an articulation of ideas that had their genesis in those deliberations.

Academic librarians, library school educators, and higher education faculty and administrators will want this book.
Association Of COLLEGE \& RESEARCH LIBRARIES

Association Of COLLEGE \& RESEARCH LIBRARIES

Association Of COLLEGE \& RESEARCH LIBRARIES

Association Of C OLLEGE \& RESEARCH LIBRARIES

A OIVISION OF THE AMERICAN IHBRARY ASSOCIATION 